\title{
The Relationship Between Stress Levels and Quality of Life of Diabetics in the Working Area of Wangon 1 Public Health Center in 2019
}

\author{
$1^{\text {st }}$ Bela Ardilla \\ Undergraduate Science of Nursing Student \\ Faculty of Health Science, Harapan Bangsa \\ University \\ Purwokerto, Indonesia \\ Email: bellaardila@uhb.ac.id
}

\author{
$2^{\text {nd }}$ Pramesti Dewi \\ Nursing Lecturer \\ Faculty of Health Science, Harapan Bangsa \\ University \\ Purwokerto, Indonesia \\ Email: pramesti.shb@gmail.com
}

\author{
$3^{\text {rd }}$ Azka Fathiyatir Rizqillah \\ Nursing Lecturer \\ Faculty of Health Science, Harapan Bangsa \\ University \\ Purwokerto, Indonesia \\ Email : azkafathiyatir@uhb.ac.id
}

\begin{abstract}
Diabetes Mellitus (DM) is a chronic disease that causes high morbidity and mortality. Complications of DM can be categorized as serious problems because the presence of these complications can affect the quality of life of patients. Stress is common in someone with diabetes and requires proper treatment because it causes severe damage to quality of life. The purpose of this research was to analyze the relationship between stress levels and quality of life of diabetics in the working area of 1 Wangon Public Health Center. The research design was an analytical survey with a cross-sectional approach. The sampling technique used was purposive sampling. The samples were people with diabetes mellitus (85 respondents) in the working area of Wangon 1 Public Health Center. The research instrument used was a questionnaire, and the statistical analysis used was Spearman rank. The results showed that the majority of respondents was in middle adulthood (41-65 years) $(89.4 \%)$; most respondents were female $(56.5 \%)$; most respondents had basic education (elementary-junior high school) (72.9\%); and most respondents were employed $(64.7 \%)$. Moreover, most of them had a moderate stress level $(\mathbf{4 9 . 4 \%})$ and a moderate quality of life $(54.1 \%)$. There was a correlation between stress level and quality of life of diabetics in the working area of Wangon 1 Public Health Center in 2019 with $\rho$-value of $0,0001(\rho$-value $\leq \alpha(0,05))$.
\end{abstract}

Keywords: stress levels, quality of life, diabetes mellitus

\section{INTRODUCTION}

Diabetes mellitus (DM) is a chronic disease that causes high morbidity and mortality. Diabetes mellitus is a group of metabolic diseases characterized by high levels of glucose in the blood (hyperglycemia) that occurs due to impaired insulin secretion, decreased insulin action, or both (American Diabetes Association [1]. The International Diabetes Federation (IDF) in 2014 predicted that of 220 countries around the world, the number of people with diabetes mellitus was predicted to increase from 415 million people in 2015 to 642 million in 2040. Nearly half of them lives in Asia, mainly India, China, Pakistan, and Indonesia. The country with the highest diabetes case was in
China in which 98.4 million cases were found in 2018 and it is predicted to reach 142.7 million in 2035 [2].

Based on Riskesdas (Basic Health Research) data (2018) diabetics in Indonesia have increased in the last five years, in 2013 diabetics reached $6.9 \%$ or around $12,191,564$ people. The number of diabetics increased and reached $8.5 \%$ or around $15,018,594$ people in 2018 , though the prevalence of DM in Central Java increased by $1.6 \%$ in 2013 to $2.1 \%$ in 2018.[3]

Based on the data from the Banyumas District Health Office (2016), it was found that the incidence of Non-Insulin Dependent Diabetes Mellitus (NIDDM) was 1558 cases in 2016, while the incident of Insulin-Dependent Diabetes Mellitus (IDDM) was 288 cases. Wangon 1 public health center is a health center with the most cases of DM in Banyumas having 166 cases of Non-Insulin Dependent Diabetes Mellitus (NIDDM) and 5 cases of Insulin-Dependent Diabetes Mellitus (IDDM).

An increase in the number of people with DM will have an impact on health because DM is a chronic disease that will be experienced by patients for life. Chronic complications of DM can be in the form of microvascular and macrovascular complications which can reduce the quality of life of patients. The main cause of death for people with DM is macrovascular complications. Macrovascular complications involve large blood vessels namely coronary arteries, cerebral blood vessels, and peripheral blood vessels. On the other hand, microvascular complications including a specific skin lesion in diabetes attack the capillaries and retinal arterioles (diabetic retinopathy), renal glomerulus (diabetic nephropathy), and peripheral nerves (diabetic neuropathy).[4]

Quality of life is an important factor that can affect a person's health condition. Poor quality of life will worsen the condition of a disease and vice versa. Disease can cause a decrease in the quality of life of a person, especially chronic diseases that are quite difficult to cure such as diabetes mellitus.

Research results showed that the quality of life of diabetics was bad (36.7\%). [5] Research in India showing that patients with diabetes mellitus required holistic care for their mental well-being and quality of life instead of their physical health. [6] 
The quality of life of patients with diabetes mellitus is influenced by several factors: demographic factors such as age and marital status, medical factors such as length of suffering and complications experienced, and psychological factors such as depression, stress, and anxiety [7]. A study showed that depression and stress of people with diabetes are common and proper treatment is required to avoid severe damage affecting the quality of life [8].

Stress experienced by people with diabetes mellitus can increase blood sugar levels through an increase of sympathoadrenal stimulus. Stress affects someone's appetite and makes patients hungry, especially on foods high in carbohydrates and fats, thus stress can be a serious health problem for people with diabetes mellitus because their blood sugar can become difficult to control [9].

Stress is the unspecified body's response to any needs of the body and a universal phenomenon in everyday life. Stress cannot be avoided, and everyone experiences it. Stress absolutely can influence physical, psychological, intellectual, social, spiritual, and physiological factors. Stress can threaten the physiological balance. The results indicated that most of them had severe stress (25 respondents, 52\%), moderate stress (20 respondents, $42 \%$ ), and mild stress (3 respondents, 6\%). [10].

Based on the background above, the researchers intended to find out "The relationship between stress levels and quality of life of diabetics in the working area of Wangon 1 Public Health Center in 2019".

\section{MethodS}

The research design was an analytical survey with a cross-sectional approach. The sampling technique used was purposive sampling technique which is a technique selected based on the characteristics of respondents to meet the research problems. The samples were people with diabetes mellitus (85 respondents) in the working area of Wangon 1 Public Health Center. The research instrument used was a questionnaire. The statistical analysis used was Spearman rank.

\section{RESULTS AND DISCUSSION}

The results showed that most respondents were in middle adulthood (41-65 years) (76 respondents, 89.4\%) (Table 1). Age affects the risk and incidence of DM. Age is very closely related to the increase in blood glucose levels, thus as age increases the prevalence of DM and impaired glucose tolerance is higher. The aging process occurs after 30 years old resulting in anatomical, physiological and biochemical changes. According to WHO after 30 years old, blood glucose levels will increase to $1-2 \mathrm{mg}$ /dL/year during fasting and will increase to 5.6-13 $\mathrm{mg} / \mathrm{dL}$ in 2 hours after eating (Sudoyo et al, 2009). Type 2 Diabetes Mellitus (DM) is a DM that often occurs in adults over 35 years [11].
TABLE 1. FREQUENCY DISTRIBUTION OF CHARACTERISTICS OF DIABETICS BY AGE, GENDER, EDUCATION, AND EMPLOYMENT STATUS IN THE WORKING AREA OF WANGON 1 PUBLIC HEALTH CENTER IN 2019 (N: 85)

\begin{tabular}{|c|c|c|c|}
\hline \multicolumn{2}{|c|}{ Characteristics of Respondents } & Frequency & Percentage \\
\hline \multirow[t]{3}{*}{ Age } & Early Adults & 4 & 4,7 \\
\hline & Middle Adults & 76 & 89,4 \\
\hline & Elderly & 5 & 5,9 \\
\hline \multirow[t]{2}{*}{ Gender } & Male & 37 & 43,5 \\
\hline & Female & 48 & 56,5 \\
\hline \multirow[t]{4}{*}{ Education } & No Formal Education & 1 & 1,2 \\
\hline & Primary & 62 & 72,9 \\
\hline & Secondary & 20 & 23,5 \\
\hline & Tertiary & 2 & 2,4 \\
\hline \multirow{3}{*}{$\begin{array}{c}\text { Employment } \\
\text { Status }\end{array}$} & Unemployed & 30 & 35,3 \\
\hline & Employed & 55 & 64,7 \\
\hline & Total & 85 & 100 \\
\hline
\end{tabular}

In line with what was presented by Awad in his study, mos diabetics were at the age of 51-60 and in general the most patients were at the age of 40-60 [12]. A person over the age of 46 has an increased risk of developing DM and glucose intolerance caused by degenerative factors such as decreased body function, specifically the ability of $\beta$ cells to produce insulin to metabolize glucose [13].

The results of this research showed that most of respondents were females (48 respondents, 56.5\%) (Table 1). Women have more risks of developing diabetes because physically they have a greater chance of increasing body mass index and a greater relationship of hormonal process factors than men associated with the monthly menstrual cycle (premenstrual syndrome). Women aged more than 40 years experience hormonal changes showing a decrease in the estrogen and progesterone hormones. Estrogen functions to maintain a balance of blood sugar levels and increase fat storage, and progesterone functions to normalize blood sugar levels and help use fat as energy.

The results of this research were in line with the other research in which type 2 DM predominantly occurs in women than in men. There was no difference in the prevalence of type 2 DM between men and women under 25 years old. However, the prevalence of DM in women at the age of 25-34 was 20\% than in men. The prevalence of DM became $60 \%$ at the age of 35-44 and at the age of 45-64 the prevalence of type $2 \mathrm{DM}$ in women was two times higher than in men [14]. Another study found that the prevalence of DM in women was higher than in men related to the chance of increasing BMI and hormonal factors [15].

The results also showed that most respondents had primary education (elementary-junior high school) (62 respondents, $72.9 \%$ ) (Table 1). Education is related to behavior to maintain and improve their health. Education for respondents was related to behavior in controlling blood sugar levels to remain stable within normal limits. Education is a means of promotion or learning shared to the community, thus people do actions to maintain or overcome problems, and improve their health [16].

Many respondents also had low education (elementaryjunior high school) and this influenced the knowledge of respondents which is the higher the level of education, the higher the level of knowledge about health. Education is one of the 
factors that can influence a person's knowledge. It can be stated that the higher a person's education is, the easier a person receives information and the more knowledge a person has. Conversely, if education is low, it will influence the development of one's attitude to receive information or newly introduced values [17]. Trisnawati's study showed that 50 respondents having low education experienced type 2 DM in Public Health Center, Cengkareng, West Jakarta [18].

The results also showed that most respondents worked (55 respondents, 64.7\%) (Table 1). One's job is related to the demands of the achieved task or target. If someone fails to meet the demands of the task and the target, s/he will experience stress.

Stress causes overproduction of cortisol hormone. Cortisol is a hormone that counteracts the effects of insulin and causes high blood sugar levels. If someone experiences severe stress, the body produces more cortisol and this will decrease the sensitivity of the body against insulin. In this case, cortisol and insulin play the opposite role. Stress can increase cortisol hormone, and thus it is quite difficult for glucose to get into the cells and finally blood sugar level increases. [19].

One's job is also associated with activities in daily life. Activities carried out by people with diabetes mellitus increase the use of energy in the body and therefore it can reduce blood sugar levels. The results of this research were also in line with the results of research conducted by Diani showing that the majority of people with diabetes mellitus were still working, and this was associated with their physical activity. Activity is one of the pillars of diabetes mellitus management in managing diabetes mellitus and preventing complications [20]. Another research showed that respondents who did not work had 1.6 times the risk of complications compared to those who worked [21].

The results showed that most respondents had a moderate stress level (42 respondents, $49.4 \%$ ) (Table 2). DM is a chronic disease that is very influential on the onset of the stress of diabetics. People with diabetes have to change their lifestyles by applying dietary restrictions, doing exercise, consuming medicine regularly, and controlling blood sugar. Those changes will certainly lead to psychological reactions in negative responses such as anger, anxiety, and stress [22].

DM patients are required to do things which can change their lifestyles. If they ignore it, complications such as anxiety, anger, stress or even depression will arise [23].

Diabetes patients must depend on therapy. This therapy can cause problems such as feeling weak because of dietary restrictions. Any changes in health can be a stressor. Diabetes Mellitus patients must change their lifestyle, thus blood sugar in the body remains balanced. If not changing their lifestyles, they will experience stress. Stress occurs if the resources do not match the demands of the situation. When the situation demands are different from the previous situation and too hard, stress occurs. High-stress levels can trigger a person's blood sugar levels to increase indicating the higher the stress level of DM patients, the worse the DM [24].
TABLE 2. FREQUENCY DISTRIBUTION OF STRESS LEVELS OF DIABETICS IN THE WORKING AREA OF WANGON 1 PUBLIC HEALTH CENTER IN 2019 (N: 85)

\begin{tabular}{|c|l|c|c|}
\hline No & \multicolumn{1}{|c|}{ Stress Levels } & Frequency & Percentage \\
\hline 1. & Mild Stress & 38 & 44,7 \\
\hline 2. & Moderate Stress & 42 & 49,4 \\
\hline 3. & Severe Stress Total & 5 & 5,9 \\
\hline & \multicolumn{2}{|c|}{ Tol } \\
\hline
\end{tabular}

TABLE 3. FREQUENCY DISTRIBUTION OF STRESS LEVELS OF DIABETICS BY DOMAINS IN THE WORKING AREA OF WANGON 1 PUBLIC HEALTH CENTER IN 2019 (N: 85)

\begin{tabular}{|c|c|c|c|c|c|c|c|c|}
\hline \multirow{3}{*}{ Domains } & \multicolumn{6}{|c|}{ Stress Levels } & \multirow{2}{*}{\multicolumn{2}{|c|}{ Total }} \\
\hline & \multicolumn{2}{|c|}{ Mild } & \multicolumn{2}{|c|}{ Moderate } & \multicolumn{2}{|c|}{ Severe } & & \\
\hline & f & $\%$ & $\mathbf{f}$ & $\%$ & $\mathbf{f}$ & $\%$ & f & $\%$ \\
\hline Emotional Burden & 45 & 52,9 & 35 & 41,2 & 5 & 5,9 & 85 & 100 \\
\hline $\begin{array}{c}\text { Physician-Related } \\
\text { Distress }\end{array}$ & 47 & 55,3 & 20 & 23,5 & 18 & $\begin{array}{c}21, \\
2\end{array}$ & 85 & 100 \\
\hline $\begin{array}{l}\text { Regimen-Related } \\
\text { Distress }\end{array}$ & 42 & 49,4 & 34 & 40 & 9 & $\begin{array}{c}10, \\
6\end{array}$ & 85 & 100 \\
\hline $\begin{array}{c}\text { Interpersonal } \\
\text { Distress }\end{array}$ & 52 & 61,2 & 16 & 18,8 & 17 & 20 & 85 & 100 \\
\hline
\end{tabular}

Stress can increase blood glucose content because stress stimulates endocrine organs to release epinephrine. Epinephrine has a very powerful effect on the onset of the gluconeogenesis process in the liver, and thus it will release large amounts of glucose into the blood within minutes. This causes an increase in blood glucose levels when stressed or strained. Some things causing blood sugar to increase are lack of exercise, an increase in the amount of food consumed, an increase in stress and emotional factors, weight gain and age, and the impact of treatment from drugs, such as steroids [25].

Other researchers found that there was a relationship between stress levels and an increase in blood sugar levels in Diabetes Mellitus patients in Rasimah Ahmad Bukittinggi Urban Health Center $(p=0.017)$ [24]. The lowest value of diabetes distress was 1.06 and the highest value was 3.88 . The highest percentage of diabetes distress was in moderate distress (43 people, 51\%) [26].

Stress associated with DM is called diabetes distress. Diabetes distress is an emotional problem directly related to the burden or worries of living with chronic diseases such as DM. This situation is marked by feelings of worry, frustration, and fatigue [27]. Diabetes distress has 4 domains namely emotional burden distress, physician-related distress, regimen-related distress/distress management, and interpersonal distress. The results of this research showed 4 domains of diabetes distress namely emotional burden distress (2.28), regimen-related distress (2.14), physician-related distress (2.09) and interpersonal distress (1.90). This was in line with the results of other research showing that the most dominant component of distress towards patient distress was an emotional burden distress. [28]

The results showed that the indicator value of the emotional burden had lower diabetes distress. Respondents did not feel depressed, had a burden, and felt overwhelmed living with DM, but they could still manage their emotions.

Emotional distress is an evaluation of an emotional burden that refers to a person's emotional states such as fear, anxiety, 
being overwhelmed with diabetes and he feels that diabetes controls his life [29]. DM patients feel that they do not have the opportunity to enjoy their lives like consuming sugar. Moreover, the severity and even the risk of death can trigger an emotional burden on the patient. When patients are unable to manage their emotions, those emotions can be a source of stress which can trigger stress in DM patients [28].

Emotional burden has a negative impact that can interfere with physical and emotional well-being in which patients perform self-care such as regulating dietary patterns, doing exercise, monitoring blood glucose, and complying with any recommended daily treatment [30]. DM patients need treatment to overcome emotional problems associated with DM aiming to help patients receive and manage their disease [31].

The results of this research also showed that the highest value of diabetes distress was health workers-related distress. This showed that the relationship between patients and health workers needed an improvement. Health workers did not help patients in managing illnesses and patients did not utilize health services in supporting diabetes management. Based on this situation, patients assumed that the health workers did not know about diabetes and diabetes management (treatment), did not provide information about diabetes treatment clearly, and did not care about patients seriously. Moreover, patients did not have any health workers who could be met to always check their condition.

Relationships are bonds between patients and health workers in the form of communication to build patients' trust. Patients' trust is obtained from the medical promises with health workers, the ways the patients treated, and the care given by health workers to patients [32]. The more the patients believe in health workers, the better the patients undergo diabetes self-care such as diet, exercise, blood glucose monitoring, and adherence to treatment. Building trust between health workers and patients can alleviate patients' problems in performing self-care activities [30].

The results showed that most respondents had a moderate quality of life (46 respondents, 54.1\%) (Table 4). It indicates that DM treatment takes a long time since it is a chronic disease and is very complex. Actually, it does not only require treatment but also lifestyle changes. Patients often become discouraged with the therapy program. Condition that can affect the physical, psychological, social health, and well-being of people with diabetes mellitus is defined as a quality of life [33].

Research on Assessing Psychosocial Distress in Diabetes showed that patients with DM experienced a decrease in quality of life that is caused by physical illness, treatment processes, and complications. Diabetes can reduce physical function due to long-term complications caused by the disease itself and health conditions related to DM. Impairment of visual acuity, kidney disorders, heart disease, erectile disorders, pain due to peripheral neuropathy, risk of amputation, autonomic nerve damage will greatly reduce the quality of life of patients because it will limit the physical activity of patients either directly or indirectly. The demands of therapy often make patients feel restricted [34].
TABLE 4. FREQUENCY DISTRIBUTION OF QUALITY OF LIFE OF DIABETICS IN THE WORKING AREA OF WANGON 1 PUBLIC HEALTH CENTER IN 2019 (N: 85)

\begin{tabular}{|c|c|c|c|}
\hline No & Quality of Life & Frequency & Percentage \\
\hline 1. & Low & 0 & 0 \\
\hline 2. & Medium & 46 & 54,1 \\
\hline 3. & High & 39 & 45,9 \\
\hline & Total & 85 & 100 \\
\hline
\end{tabular}

TABLE 5. FREQUENCY DISTRIBUTION OF QUALITY OF LIFE OF DIABETICS BY DOMAINS IN THE WORKING AREA OF WANGON 1 PUBLIC HEALTH CENTER IN 2019 (N: 85)

\begin{tabular}{|c|c|c|c|c|c|c|c|c|}
\hline \multirow{3}{*}{ Domains } & \multicolumn{6}{|c|}{ Quality of Life } & \multirow{2}{*}{\multicolumn{2}{|c|}{ Total }} \\
\hline & \multicolumn{2}{|c|}{ Low } & \multicolumn{2}{|c|}{ Medium } & \multicolumn{2}{|c|}{ high } & & \\
\hline & f & $\%$ & $\mathbf{f}$ & $\%$ & $\mathbf{f}$ & $\%$ & $\mathbf{f}$ & $\%$ \\
\hline Satisfaction & 0 & 0 & 14 & 16,5 & 71 & 83,5 & 85 & 100 \\
\hline Impact & 3 & 3,5 & 64 & 75,3 & 18 & 21,2 & 85 & 100 \\
\hline $\begin{array}{l}\text { Concerns } \\
\text { related to } \\
\text { diabetes }\end{array}$ & 3 & 3,5 & 39 & 45,9 & 43 & 50,6 & 85 & 100 \\
\hline Sosial Concerns & 5 & 5,9 & 42 & 49,4 & 38 & 44,7 & 85 & 100 \\
\hline
\end{tabular}

The results showed that respondents had a medium quality of life. This was related to respondents' education indicating that having low education will result in a low quality of life of DM patients [35]. The quality of life of diabetics was bad $36.7 \%$ [5]. The results were in line with the study of Annies (2016) found that 77 people $(52.7 \%)$ were in a good quality of life and 69 people $(47.3 \%)$ were in a low quality of life.

The quality of life of respondents was mostly in a medium category. It revealed that respondents were less satisfied or dissatisfied with their current health, and few respondents assumed that they could not be fit anymore, especially for those suffering from DM for a long time. Based on the satisfaction assessment, $83.5 \%$ of respondents had a high quality of life, and in average respondents were satisfied with their quality of life. In line with the other research, respondents felt satisfied with their quality of life [36]. Likewise, Ningtyas stated that in the average quality of life of her respondents showed satisfaction. [37]

Based on the assessment of social concerns, 3 respondents had a low quality of life $(3.5 \%)$. Social support for Diabetes Mellitus patients can be found in patients' perceptions of social support from their families. Social supports include responsibility, support, and assistance/help from family and friends. The family support has an impact on the physical and mental health of its members. Poor family support is associated with an increase in morbidity and mortality [38].

In addition to impaired physical function, anxiety and irritability also limit social activities that can make individuals feel bad and have a low quality of life [39]. Several studies reported that psychological factors are closely related to blood sugar control, such as daily activities, stress, self-efficacy, and social support [39].

Respondents with low quality of life on social/occupational concerns had a decrease in completing tasks including limiting themselves from various activities, delaying several activities, and finding difficulties in completing a task. The results of this research also showed that there were no 
Stress which is accompanied by other emotional states has respondents with a low quality of life $(0 \%)$ because the samples were diabetics who did not experience complications.

TABLE 6. RELATIONSHIP BETWEEN STRESS LEVELS AND QUALITY OF LIFE OF DIABETICS IN THE WORKING AREA OF WANGON 1 PUBLIC HEALTH CENTER IN 2019 (N: 85)

\begin{tabular}{|c|c|c|c|c|c|c|c|}
\hline \multirow{3}{*}{ Stress Levels } & \multicolumn{6}{|c|}{ Quality of Life } & \multirow{2}{*}{$\boldsymbol{\rho}$-value } \\
\cline { 2 - 8 } & \multicolumn{2}{|c|}{ Low } & \multicolumn{1}{|c|}{ Medium } & \multicolumn{2}{c|}{ High } & \\
\cline { 2 - 7 } & $\mathbf{f}$ & $\mathbf{\%}$ & $\mathbf{F}$ & $\mathbf{\%}$ & $\mathbf{f}$ & $\mathbf{\%}$ & \\
\hline Mild & 0 & 0 & 9 & 10,6 & 29 & 34,1 & \multirow{2}{*}{0,0001} \\
\hline Moderate & 0 & 0 & 32 & 37,6 & 10 & 11,8 & \\
\hline Severe & 0 & 0 & 5 & 5,9 & 0 & 0 & \\
\hline Total & 0 & 0 & 46 & 54,1 & 39 & 45,9 & CC: $-0,559$ \\
\hline
\end{tabular}

The results showed that respondents with a mild stress mostly had a high quality of life $(34.1 \%)$, respondents with a moderate stress level mostly had a moderate quality of life (37.6\%), and respondents with severe stress level had moderate quality of life $(5,9 \%)$. The spearman-rank test result was $\rho$-value of 0.0001 showing $\rho$-value $\leq \alpha(0.05)$ in which there was a relationship between stress levels and quality of life of people with diabetes mellitus. The correlation coefficient obtained was 0.559 showing that there was a strong negative relationship indicating the lower the stress level of respondents, the higher the quality of life of respondents.

Effects of stress experienced by people with diabetes mellitus are stressors experienced continuously, changes in lifestyle, medication, treatment, complications, environmental conditions, and lack of support. Daily stressors can cause an increase in blood sugar and reduce short-term psychological well-being, and produce physical symptoms, and thus daily stressors can produce stress and worsen physical and psychological health. In addition to daily stressors, personality factors also influence the levels of stress and individuals' quality of life with diabetes mellitus [39].

The symptoms caused by uncontrolled blood sugar can interfere with one's daily activities and reduce physical, psychological and social functions. A person with diabetes will have lack of energy and thus he gets tired easily of doing daily activities. Besides, he had lack of physical activities, roles, and responsibilities. In addition to impaired physical function, anxiety and irritability also limit social activities that can make individuals feel bad and have a low quality of life.[40].

In a study conducted by Spencer, it was found that stress is associated with the disease due to the burden of self-care such as monitoring sugar levels, taking medication, monitoring food intake, and exercising regularly. Diabetes-related stress is a significant contributor to the low adherence to diabetes self-care as recommended and low blood sugar control that has an impact on individuals including interpersonal, social and work [39].

The psychological condition of DM patients is also closely related to the cognitive and emotional aspects of coping strategies for disease (disease-coping strategies) affecting the drug-seeking habits indirectly. Assessment or subjective awareness of DM patients indicates that DM patients adhere to the treatment that can affect the quality of life of patients [41]. an impact on adhering or abandoning the management of diabetes by diabetics. It describes the higher the stress, the more the emotional problems experienced by people with diabetes mellitus. This is related to a decrease in adherence to the management of diabetes mellitus treatment, and therefore their blood sugar levels will tend to increase and it will have an impact on a decrease in quality of life of DM patients.

The majority of respondents in this research were elderly. In this case, several respondents had vision problems and lack of enthusiasm. Thus, the researchers needed much time to explain each questionnaire and could not complete this research on target.

\section{CONCLUSION}

Based on the results, most people with diabetes mellitus in the working area of Wangon 1 Public Health Center in 2019 were in middle adulthood (41-65 years) (89.4\%); they were female $(56.5 \%)$; they had basic education (elementary-junior high school) (72.9\%); and they were employed (64.7\%). Moreover, most people with diabetes mellitus had a moderate stress level (49.4\%), and a moderate quality of life (54.1\%).

In conclusion, there was a relationship between stress levels and quality of life of diabetics in the working area of Wangon 1 Public Health Center in 2019 ( $\rho$-value of 0.0001) showing $\rho$ value $\leq \alpha(0.05)$. The correlation coefficient (-0.559) showed medium strength with negative relationship indicating the lower the stress level of respondents, the higher the quality of life of respondents.

\section{SugGESTIONS}

Based on this research, it is suggested that DM patients should always maintain their psychological condition to avoid carrying out spiritual activities that can calm their soul.

Besides, support of patients' family is needed to assist DM patients in managing stress and improving the quality of life after being diagnosed with DM. Families are also expected to always motivate diabetics about the importance of controlling blood sugar.

Furthermore, regarding to the management of DM, it is necessary for Puskas to provide information in the form of brochures, leaflets, and notice boards. Health centers also need to provide nursing care services and stress management for people with diabetes mellitus, therefore psychosocial problems such as stress causing a decrease in quality of life in people with diabetes mellitus can be minimized.

It is also expected for further research to consider a larger sample size for more comprehensive research results and do research using other various variables that are likely to have a relationship with the quality of life of patients. stress. Steps that can be taken including surrendering to God and 


\section{REFERENCES}

[1] ADA, "Diagnosis and classification of diabetes mellitus.," Am. Diabetes care, 2015.

[2] International Diabetes Federation (IDF), "IDF Diabetes Atlas Sixth edition, 2014 Update," Idf.Org, 2014.

[3] Riskesdas, "Riset Kesehatan Dasar 2018," Kementrian Kesehat. Republik Indones., 2018.

[4] D. A. Edwina, A. Manaf, and Efrida, "Pola Komplikasi Kronis Penderita Diabetes Melitus Tipe 2 Rawat Inap di Bagian Penyakit Dalam RS. Dr. M. Djamil Padang Januari 2011 - Desember 2012," J. Kesehat. Andalas, 2015.

[5] J. M. Laoh and D. Tampongangoy, "MELLITUS DI POLIKLINIK ENDOKRIN," JUIPERDO, 2015.

[6] V. Jain, S. Shivkumar, and O. Gupta, "Health-related quality of life (Hr-Qol) in patients with type 2 diabetes mellitus," N. Am. J. Med. Sci., 2014.

[7] B. Smet, "Psikologi kesehatan," J. Public Health (Bangkok)., 2012.

[8] K. Yudianto, H. Rizmadewi, and I. Maryati, "Kualitas Hidup Penderita Diabetes Mellitus Di Rumah Sakit Umum Daerah Cianjur," Kualitas Hidup Penderita Diabetes Mellit., 2008.

[9] A. Widodo, "Stress pada Penderita Diabetes Mellitus Tipe-2 dalam Melaksanakan Program Diet di Klinik Penyakit Dalam RSUP Dr. Kariadi Semarang," Medica Hosp. - J. Clin. Med., 2012.

[10] S. Adi Nugroho, "Hubungan Antara Tingkat Stres dengan Kadar Gula Draah pada Pasien Diabetes Mellitus di Wilayah Kerja Puskesmas Sukoharjo I Kabupaten Sukoharjo," Univ. Muhammadiyah Semarang, 2010.

[11] Elisa, "Buku Ajar Keperawatan Medikal Bedah Brunner \& Suddarth edisi 8 Volume 1,2. Jakarta: penerbit Buku Kedokteran Indonesia EGC.," Water (Switzerland), 2016.

[12] N. Awad, Y. A. Langi, and K. Pandelaki, "GAMBARAN FAKTOR RESIKO PASIEN DIABETES MELITUS TIPE II Di POLIKLINIK ENDOKRIN BAGIAN/SMF FK-UNSRAT RSU Prof. Dr. R.D KANDOU MANADO PERIODE MEI 2011 - OKTOBER 2011," J. $e$ Biomedik, 2013.

[13] R. Betteng, “ANALISIS FAKTOR RESIKO PENYEBAB TERJADINYA DIABETES MELITUS TIPE 2 PADA WANITA USIA PRODUKTIF DIPUSKESMAS WAWONASA," J. e-Biomedik, 2014.

[14] E. A. M. Gale and K. M. Gillespie, "Diabetes and gender," Diabetologia. 2001.

[15] R. A. Harista and R. Lisiswanti, "Depresi pada Penderita Diabetes Mellitus Tipe 2," Majority, 2015.

[16] S. Notoatmodjo, Promosi Kesehatan dan Perilaku Kesehatan Edisi 2012. 2012.

[17] E. dan W. Sutrisno, "Proses Pendidikan Dasar dan Menenga," etalase.unnes, 2009.

[18] S. K. Trisnawati and S. Setyorogo, "Faktor Risiko Kejadian Diabetes Melitus Tipe II Di Puskesmas Kecamatan Cengkareng Jakarta Barat Tahun 2012," J.
Ilm. Kesehat., 2013.

[19] P. J. Watkins, "ABC of diabetes: The diabetic foot," British Medical Journal. 2003.

[20] N. Diani, A. Waluyo, and L. Sukmarini, "PENGETAHUAN KLIEN TENTANG DIABETES MELITUS TIPE 2 Pendahuluan Metode," J. Keperawatan Indones., 2013.

[21] Z. Arifin, “Analisis Hubungan Kualitas Tidur Dengan Kadar Glukosa Darah Pasien Diabetes Melitus Tipe 2 Di Rumah Sakit Umum Propinsi Nusa Tenggara Barat," Tesis, 2011.

[22] A. Bener, "High Prevalence of Depression, Anxiety and Stress Symptoms Among Diabetes Mellitus Patients," Open Psychiatr. J., 2011.

[23] L. E. Purwanti and S. Maghfirah, "Faktor Risiko Komplikasi Kronis (Kaki Diabetik) Dalam Diabetes Mellitus Tipe 2," Indones. J. Heal. Sci., 2016.

[24] W. Izzati and Nirmala, "KADAR GULA DARAH PADA PASIEN DIABETES MELLITUS DI WILAYAH KERJA PUSKESMAS PERKOTAAN RASIMAH AHMAD BUKIT TINNGI TAHUN 2015," Keperawatan, 2015.

[25] P. Pratiwi, G. Amatiria, and M. Yamin, "Pengaruh Stress Terhadap Kadar Gula Darah Sewaktu Pada Pasien Diabetes Melitus Yang Menjalani Hemodialisa," J. Kesehat., 2014.

[26] I. Inayah, M. Y. Hamidy, and M. Sari, "Gambaran Terapi Diabetes Melitus Tipe 2 dengan Komorbid Hipertensi di Rumah Sakit X Pekanbaru," J. Ilmu Kedokt., 2017.

[27] D. M. Hessler, L. Fisher, J. T. Mullan, R. E. Glasgow, and U. Masharani, "Patient age: A neglected factor when considering disease management in adults with type 2 diabetes," Patient Educ. Couns., 2011.

[28] E. O. Purwasih, I. Permana, and Y. Primanda, "RELAKSASI BENSON DAN TERAPI MUROTTAL SURAT AR-RAHMAAN MENURUNKAN KADAR GLUKOSA DARAH PUASA PADA PENDERITA DIABETES MELITUS TIPE 2 DI KECAMATAN MAOS," J. Ilm. Kesehat. Keperawatan, 2017.

[29] A. Ş. Mocan and A. Bəban, “An useful toolf for diabetes emotional distress assessment: Validation of the Romanian version of diabetes distress scale," Rom. J. Diabetes, Nutr. Metab. Dis., 2015.

[30] M. Niazi and R. Rafique, "Patient-physician trust, emotional distress, and self-care activities of adults with type II diabetes mellitus," Pakistan J. Psychol. Res., 2017.

[31] "The Relationship between Stress and Diabetes Mellitus," J. Neurol. Psychol., 2015.

[32] E. A. Beverly, M. D. Ritholz, C. Shepherd, and K. Weinger, "The Psychosocial Challenges and Care of Older Adults with Diabetes: 'Can't Do What I Used To Do; Can't Be Who I Once Was," Current Diabetes Reports. 2016.

[33] N. Aini, W. Fatmaningrum, and A. Yusuf, "Upaya 
Meningkatkan Perilaku Pasien Dalam Tatalaksana Diabetes Mellitus Dengan Pendekatan Teori Model Behavioral System Dorothy E.Johnson," J. Ners, 2011.

[34] R. A. Polonsky, W.H., Fisher, L., Earles, J., Dudl, R.J., Lees, J., Mullan, J. and Jackson, "Assessing Psychosocial Distress in Diabetes," Diabetes Care, 2005.

[35] B. A. Issa and O. Baiyewu, "Quality of life of patients with diabetes mellitus in a Nigerian Teaching Hospital," Hong Kong J. Psychiatry, 2007.

[36] A. Yusra, "Hubungan antara dukungan keluarga dengan kualitas hidup pasien diabetes mellitus tipe 2 di poliklinik penyakit dalam rumah sakit umum pusat fatmawati Jakarta," 2011.

[37] D. W. Ningtyas, dr. P. Wahyudi, and I. Prasetyowati, "Analisis Kualitas Hidup Pasien Diabetes Melitus Tipe 2 di RSUD Bangil Kabupaten Pasuruan," Artik. Ilm. Has. Penelit. Mhs., 2013.

[38] N. Retnowati and P. Satyabakti, "The Correlation between Family Support with the Quality of Life of Patients with Diabetes Mellitus," J. Berk. Epidemiol., 2015.

[39] M. D. Kusumadewi, "PERAN STRESOR HARIAN, OPTIMISME DAN REGULASI DIRI TERHADAP KUALITAS HIDUP INDIVIDU DENGAN DIABETES MELITUS TIPE 2," Psikoislamika J. Psikol. dan Psikol. Islam, 2011.

[40] Zainuddin, W. Utomo, and Herlina, "Hubungan Stres dengan Kualitas Hidup Penderita Diabetes Mellitus Tipe 2," J. Med. UNRI, 2015.

[41] R. D. Astuti, F. Nashori, and R. R. Kumolohadi, "RATIONAL EMOTIVE BEHAVIOR THERAPY SEBAGAI UPAYA MENINGKATKAN KUALITAS HIDUP PENDERITA DIABETES MELLITUS," $J$. Interv. Psikol., 2011. 